\title{
Diffusion of Web 2.0 Applications in Academic Libraries in the U.S."
}

미국 대학 도서관에서의 웹 2.0 어플리케이션 확산에 관한 연구

Soojung $\operatorname{Kim}(\text { 김수정 })^{* *}$

\begin{abstract}
This paper examines the extent and rate of adoption of five Web 2.0 applications (RSS, blog, tagging, podcast, and wiki) in 111 American Research Association (ARL) libraries and identifies institutional factors associated with Web 2.0 adoption. The popularity of Web 2.0 continues to grow, both in terms of the total number of adopting libraries and the adoption rate. Wiki adopter libraries are in larger universities, have larger professional staff, and are more acceptable to electronic resources than the non-adopters.

\section{초 록}

본 연구는 111 개 북미연구도서관협회 멤버 도서관들을 대상으로 RSS, 블로그, 태깅, 팟캐스트, 위키 등 다섯 가지 종류의 웹 2.0 어플리케이션의 수용 정도와 확산 속도를 조사하였고 확산과 관련한 기관 차원의 요인을 파악하였다. 결과적으로 웹 2.0 을 수용한 전체 도서관 수와 확산 속도로 미루어 보아 웹 2.0 기술은 계속해서 증가하고 있는 것으로 나타났다. 또한 위키를 수용한 도서관들은 수용하지 않은 도서관들에 비하여 대체로 대규모 사이즈의 대학에 속해 있고, 직원 수가 많으며, 전자 자료에 대한 수용도가 높은 것으로 밝혀졌다.

키워드: Web 2.0, Library 2.0, Diffusion of Innovations, Academic Libraries, American Research Association(ARL)

웹 2.0, 라이브러리 2.0, 혁신 확산 이론, 대학 도서관, 북미연구도서관협회
\end{abstract}

* 이 논문은 2012 년도 전북대학교 연구기반 조성비 지원에 의하여 연구되었음.

이 논문은 2011년도 한국비블리아학회 추계학술대회에서 발표한 내용을 수정·보완한 것임.

** 전북대학교 문헌정보학과 조교수, 인문영상연구소 연구원(kimsoojung@jbnu.ac.kr)

논문접수일자 : 2012년 8월 13일 논문심사일자 : 2012년 9월 5일 게재확정일자 : 2012년 9월 15일 


\section{Introduction}

Information Technology (IT) fashion is defined as "a transitory collective belief that an information technology is new, efficient, and at the forefront of practice" (Wang 2010). When such a belief is prevalent for an IT and thus, the technology is going through a hyped phase, it is described as "in fashion." As new information technologies continuously come in and go out of fashion, libraries regularly face the challenge to decide whether or not to adopt an emerging IT. A central question in the decision process is whether the innovation will become the "next big thing" with sustainable dominance or whether it will be only a passing fad (Moser 2011).

In the library world, there is no doubt that Web 2.0 has been one of the most fashionable technologies over the past years. The concept of Web 2.0 began in a conference between O'Reilly and MediaLive International in 2004 (O'Reilly 2005). Although some people argue that there is nothing inherently novel about the concept (Crawford 2006), Web 2.0 is generally perceived as the second generation of Web-based services that allow for user participation and collaboration, distinguished from the first generation that is characterized by one-way static websites. The user-centered nature of Web 2.0 not only has generated significant interest and expectations for fundamental improvement in library services, but actually has changed the way library services are delivered to users. The application of Web 2.0 thinking and technologies to library services and collections is framed as "Library 2.0" (Maness 2006).
While Web 2.0 has been discussed widely for decades and implemented in many sectors including library settings, Web 3.0, which refers to the semantic Web (Noh 2010), is being ushered in as the next generation Web.

Substantial previous research on library 2.0 in academic libraries describes the current or potential uses of Web 2.0 or provides case studies about the adoption and implementation of a specific innovation in a single library (e.g., Nielson 2008). Although the research shows how a specific Web 2.0 application was integrated into library services in a library, what is lacking in the literature is a comprehensive review of various Web 2.0 applications adopted in academic libraries as well as their adoption trends over time. To fill the research gap, the present study examines the current state of Web 2.0 and its diffusion trend over a long period of time in academic libraries. To what extent have academic libraries adopted Web 2.0? How rapidly has the innovation diffused? Is Web 2.0 still on the rise? What factors are associated with the adoption Web 2.0? These are the questions the present study aims to answer. Especially, this study examines the extent of diffusion of Web 2.0 among academic libraries between the early days of Web 2.0 and the current era by comparing data from Liu's study conducted in 2007 (Liu 2008) and that from the present study. To do that, the present study relies upon Rogers' Diffusion of Innovation theory as a theoretical framework. As the diffusion theory has been widely used to investigate the adoption and diffusion of diverse information technologies and practices in information science and other dis- 
ciplines (e.g., Yakel and Kim 2005), the theory was considered to offer an appropriate basis for analyzing Web 2.0 adoption across academic libraries.

\section{Literature Review}

\subsection{Web 2.0 in academic libraries}

A handful of studies have provided an overview of various Web 2.0 applications that are the most and least adopted in academic libraries. Perhaps, Liu's study (2008) was the first in this line of research. She proposed a conceptual model of an academic library website through the analysis of 111 Association of Research Libraries (ARL) member library websites. During the process of analysis, she identified innovative content and design features including the use of Web 2.0 applications. Regarding her data collection in December 2006, Really Simple Syndication (RSS) was the most popular Web 2.0 application adopted by thirty libraries $(27 \%)$, whereas other applications were hardly adopted at all.

Kim and Abbas (2010) analyzed 230 academic library websites randomly selected from Yahoo.com, showing that RSS and blogs were widely adopted worldwide (73\% and $65 \%$ respectively). Tripathi and Kumar (2010) similarly found that instant messaging (IM) was the most popular Web 2.0 application (43.7\%), followed by blogs (33.2\%) and RSS (31.4\%) among academic libraries in Australia, Canada, the U.K. and the U.S. More recently, Mahmood and Richardson (2011) indicated an overwhelming ac- ceptance of various Web 2.0 applications in 100 American Research Association (ARL) libraries: RSS (99\%), social networking services (SNS) (89\%), blogs $(86 \%)$, social bookmarking/tagging (55\%) and wikis $(40 \%)$. Although a direct comparison is not possible because of the different samples and different time moments the data was collected in each study, the sum of these and other studies (e.g., Harinarayana and Raju 2010) reveal a clear pattern of Web 2.0 adoption: RSS, IM, and blogs are the most widely adopted Web 2.0 applications and wikis, tagging, and podcasts are among the least adopted technologies. Kim and Abbas (2010) speculate that library-initiated applications, such as RSS, tend to be more utilized than user-initiated applications, such as tagging and wikis, because it is easier for libraries to transfer information to users, but not the other way around.

The rest of this section highlights some previous research explaining the characteristics and uses of five popular Web 2.0 applications that will be examined in the present study.

RSS resembles traditional library services, such as current awareness and selective dissemination of information (SDI), which was email-based prior to 2006. RSS automatically displays new content and reduces the need to visit a website to find out if new information is available. A variety of information can be delivered through RSS including news, blog posts, database search results, and table of contents alerts.

Literature referring to the use of blogs tends to be plentiful compared to some other types of Web 
2.0 applications because blogs have been around longer and are frequently used by many different types of libraries (Boxen 2008). Libraries have used blogs as a form of publication, like a newsletter, or as tools for marketing their resources and events or disseminating opinions. Also, blogs can be used as a tool for getting feedback from users, but Clyde found very few libraries provided interactive services in blogs (Clyde 2004).

Tagging is to assign a tag or label for a resource. In a library setting, users contribute keywords that describe the content of a resource in an online public access catalog system or in other systems. While tagging is not a direct collaboration among participants, the result of tagging is shared in the community, ultimately producing collective intelligence (Anfinnsen, Ghine, and Cesare 2011).

As a syndicated audio broadcast, a podcast has a wide appeal, particularly with undergraduate and graduate students who are digital natives (Bennington 2007) and people who are visually impaired. Academic libraries have used podcasts for promotion, and content storage of recorded lecture series, bibliographic instruction, and the full-scale creation of a library channel featuring regular news and updates (Thornton 2009).

Yoose (2011) and others wrote on the benefits of wikis, challenges, best practices, case studies, and reasons for adopting or not adopting wikis at a library.

In Korea, since 이응봉 (2007) introduced a set of Web 2.0 technologies that could be applied to digital information systems in academic libraries, many researchers have written on the adoption of library 2.0 in an academic library setting. From the perspective of users, 이지연 and 민지연 (2008) examined the users' perceptions and requirements of library 2.0 for the purpose of providing better academic information services. From the perspective of librarians, 신수연 and 김성민 (2010), and 이현실 (2007) suggested the expanded roles of librarians in library 2.0 environments.

\subsection{Diffusion of Innovation}

Rogers' Diffusion of Innovation theory is one of the most popular adoption models and has been widely used as a theoretical framework in the area of technology diffusion and adoption. The theory is concerned with how innovations are spread and why they are adopted at the individual and social levels. Rogers defines diffusion as "the process by which an innovation is communicated through certain channels over time among the members of a social system" (Rogers 1995, 5). When a new innovation emerges, a few individuals or organizations adopt its use first. Once the benefits of the innovation start to become apparent from early adopters' successful experiences, more and more individuals or organizations adopt it. Some innovations diffuse rapidly creating a steep S-curve while other innovations have a slower rate of adoption with a more gradual S-curve. The rate of diffusion is an important area of research to diffusion researchers. When studying individual choices of technology adoption and the diffusion rate, literature generally focuses on three sets of determinants (Corrocher 2011): 
- Adopters' characteristics: Rogers distinguished five categories of adopters based on the innovativeness - innovators, early adopters, early majority, late majority, and laggards.

- Attributes of the technology: Rogers' five attributes influencing the success of the technology are relative advantage, ease of use, compatibility, trialability, and observability

- The social environment: The structure of a social system and network effects within it affect an innovation's diffusion.

The present study focuses on the adopters' characteristics to examine institutional adoption of Web 2.0. Among the studies that have looked at the institutional adoption of new technologies for library services, the study closest to the present study is that of Helgren and Lietzau (2011) which analyzed the diffusion of Web 2.0 applications in public libraries. A sample of 483 public libraries, stratified by population served, was selected in 2008 and their websites were searched for blogs, RSS, virtual reference, social networking, and mobile websites. In 2010, the same library websites were revisited and the adoption rate of the individual Web 2.0 applications was calculated. By comparing the data from 2008 and 2010, they determined that the adoption of SMS (text) references, mobile websites, and social networking sites showed significant growth while blogs and email references showed little growth. In addition, regard- less of the size of population served, early adopter libraries had more librarians and staff, higher local revenues, higher staff and collection expenditures, a higher number of patron visits, and higher circulation numbers than the rest of the libraries.

Another similar study was made by White (2001). She examined the diffusion of digital reference services (DRS) in Carnegie Foundation Master's (comprehensive) academic institution libraries. Her findings were similar to those of Helgren and Lietzau (2011) in that the early adopters of DRS were most different from the other libraries. They were generally in larger institutions, wealthier, had larger staffs, were more innovative in providing computer services, and had higher demands from their clients (gate count, circulation, and reference questions). These two studies demonstrate that libraries experimenting with new technologies have more human and fiscal resources at their disposal and being early adopters positively affects outputs such as patron visits and circulation.1)

Three research questions were addressed in this study:

1) What is the extent of diffusion of Web 2.0 among academic libraries?

2) What is the rate of diffusion of Web 2.0 among academic libraries?

3) What factors are associated with the adoption of the innovation?

1) White regarded 'total circulations' and 'number of reference transactions' as existing demands for services. Her premise was that libraries with a high demand for current services might face demands from clients for additional services, for example, DRS. After statistical analysis, however, Helgren and Lietzau came to a conclusion that the number of patron visits and circulation were outputs of Web 2.0 adoption. 


\section{Methodology}

\subsection{Data Collection}

The sample of this study comprises of 111 ARL member libraries (out of 126 ARL member libraries, excluded were public libraries and academic libraries whose websites were not written in English). The author visited the individual libraries' websites to find any links or other indicators (e.g., RSS icon) of 5 types of Web 2.0 applications - RSS, blog, tagging, podcast, and wiki. These applications were selected for comparison with the study of Liu (2008), which checked the presence of the same types of applications in the same set of ARL libraries in 2006. When there is no link to such an application, a search engine within the library site was used. Google searches were also performed to find any Web 2.0 applications available outside the domain of the library sites (e.g., a library's iTune site providing podcasts). The places or systems where each application was found were recorded (e.g., RSS function in a blog; tagging in an OPAC system). Only publicly available Web 2.0 applications were checked and included. Since the data analysis unit was an individual library, any Web 2.0 application developed for collaboration across multiple libraries was excluded. The current study checked the presence or absence of each Web 2.0 application as a dichotomy. Multiple instances of single Web 2.0 applications were not considered. The data collection was conducted from April to May of 2011 and it was re-checked in July of the same year.

\subsection{Data Analysis}

In identifying the factors associated with the adoption of the Web 2.0 applications, the study used the following nine variables:

1) Scale of parent institution

- Total full-time student enrollment (TOTSTU)2)

2) Financial resources

- Total expenditures (TOTEXP)

- Expenditures for electronic serials (EXPESERL)

3) Staff resources

- Total professional staff, including librarians (PRFSTF)

- Total professional, support, and student assistant staff (TOTSTFX)

4) Degree of acceptance of electronic resources for information access

- Number of computer files (COMPFIL)

- Number of electronic serials titles (SERPURE)

5) Demands for services

- Total circulations (TOTCIRC)

- Number of reference transactions (REFTRANS)

These variables were mostly borrowed from White's study (White 2001). White explains the premises underlying the selection of these variables citing some diffusion research (for a detailed explanation, refer to White). The values for the variables were gathered from 2008-2009 ARL Statistics (ARL 2011), which was the latest data as of the data collection date. A logistic regression analysis was con-

2) Acronym as used in ARL Statistics data. 
ducted to explore the relationship between the nine variables and Web 2.0 adoption. Logistic regression analysis is often used to explain the effects of explanatory variables on binary responses. The analysis included the nine institutional variables as independent variables and the adoption of each Web 2.0 application as the binary dependent variable.

\section{Results}

\subsection{Extent of Diffusion}

Extent of diffusion is defined as the percentage of libraries providing a specific Web 2.0 application. Table 1 shows the extent of diffusion of the five Web 2.0 applications in ARL libraries.

〈Table 1> Extent of the Adoption of Web 2.0 Applications $(\mathrm{N}=111)$

\begin{tabular}{c|c}
\hline \hline & N of Adopting Libraries (\%) \\
\hline RSS & $110(99 \%)$ \\
\hline Blog & $85(77 \%)$ \\
\hline Tagging & $77(69 \%)$ \\
\hline Podcast & $37(33 \%)$ \\
\hline Wiki & $24(22 \%)$ \\
\hline
\end{tabular}

Every ARL library provided at least one of the five Web 2.0 applications and on average, three Web 2.0 applications are available per library (SD:0.915).

The most widely adopted Web 2.0 application was RSS. All libraries except one provided RSS (99\%), illustrating that the adoption of RSS was almost complete. Blogs were the second most adopted
Web 2.0 application (77\%) followed by tagging (69\%). Podcasts and wikis were the least adopted (33\% and $22 \%$, respectively). The order of popularity of these Web 2.0 applications is generally consistent with previous research (Kim and Abbas 2010; Harinarayana and Raju 2010), but their adoption rates are much higher in the current study. Probably, in comparison to the randomly or conveniently sampled sets of academic libraries in previous research, ARL member libraries are large research-intensive libraries and thus, they embrace new technologies more willingly.

Notably, the adoption of the five Web 2.0 applications is not completely independent. RSS and tagging in particular are often used in conjunction with OPACs, blogs, research guide pages, and others. More specifically, sixty three libraries provided RSS within their blogs, fifty four in research guides, and nineteen in OPACs. Likewise, forty nine libraries provided tagging in OPACs, twenty five in research guide pages, and twenty one in blogs. The aggregated deployment of Web 2.0 applications is made easier due to the presence of built-in Web 2.0 features in many library systems (e.g., AquaBrowser, Primo, \& Encore). The embedded Web 2.0 features lower the barriers to adoption of specific Web 2.0 applications.

To further identify the interrelationship among the Web 2.0 applications, a cross-tabulation was constructed. The results reveal the patterns of interrelation between blogs and tagging as well as between podcasts and wikis. Table 2 illustrates that libraries providing blogs tend to provide tagging as well. As stated earlier, this is partly due to the presence of 
the tagging feature already embedded in blog publishing platforms such as WordPress. RSS is also often used together with blogs, but since it has been adopted in almost every library, the relationship between RSS and blogs was not shown from cross-tabulation.

〈Table 2〉 Results of Cross-tabulation between Tagging and Blog

\begin{tabular}{c|c|c|c|c}
\hline \hline & & \multicolumn{2}{|c|}{ Tagging } & Total \\
\hline & & $0^{*}$ & $1^{*}$ & \\
\hline \multirow{2}{*}{ Blog } & $0^{*}$ & 6 & 20 & 26 \\
\cline { 2 - 5 } & $1^{*}$ & 28 & 57 & 85 \\
\hline Total & & 34 & 77 & 113 \\
\hline
\end{tabular}

Note: * The presence of tagging or a blog is represented by 1 and the absence by 0 .

Libraries not providing a podcast tend not to provide a wiki (Table 3). It is worth emphasizing that podcasts and wikis are independent from other applications because they are used for creating and storing content while RSS is a dissemination tool for already existing content (e.g., blog posts, OPAC search results). Therefore, barriers to implementation of podcasts and wikis are relatively high. It is speculated that libraries lacking sufficient resources and/or motivation to invest in podcasts are unlikely to develop wikis either and vice versa.

〈Table 3〉 Results of Cross-tabulation between Wiki and Podcast

\begin{tabular}{|c|c|c|c|c|}
\hline & & \multicolumn{2}{|c|}{ Wiki } & Total \\
\hline & & $0 *$ & $1^{*}$ & \\
\hline \multirow{2}{*}{ Podcast } & 0* & 60 & 17 & 77 \\
\hline & $1^{*}$ & 23 & 11 & 34 \\
\hline Total & & 83 & 28 & 113 \\
\hline
\end{tabular}

\subsection{Rate of Diffusion}

The rate of diffusion is defined as "the relative speed with which an innovation is adopted by members of a social system." Since the first adoption date of each type of Web 2.0 application in individual academic libraries is not known, it is difficult to grasp the entire diffusion process of the innovation from the start. However, drawing on data from this study and Liu's (2008), the rate of diffusion is measured as the percentage increase in the number of Web 2.0 applications adopted by ARL libraries between the time of data collection in Liu's study (December 2006) and that of the present study (May 2011). According to Liu's, in 2006, 27\% of the libraries were already offering RSS. Between December 2006 and May 2011, an additional $72 \%$ of the sample libraries began adopting RSS (Table 4). Blogs and tagging have diffused at slightly slower speeds than that of RSS. On the other hand, podcasts and wikis have diffused very gradually. As a whole, Web 2.0 has spread rapidly in ARL libraries since 2006, albeit great variations exist among the individual applications.

Based on Rogers' adopter categories, the libraries that have adopted wikis in the present study are classified mostly as innovators or early adopters (Figure 1 ), and early majority adopters are those libraries that are currently adopting wikis. Rogers characterized innovators as risk takers who are willing to adopt an unproven innovation. They tend to be financially secure and well-informed about a particular innovation. They constitute the first $2.5 \%$ segment of adopters. Early adopters serve as opinion leaders 
〈Table 4〉 Adoption Rate of Web 2.0 Applications

$(\mathrm{N}=111)$

\begin{tabular}{c|c|c|c}
\hline \hline & December 2006 & May 2011 & \\
\hline & N of Adopting Libraries (\%) & $\mathrm{N}$ of Adopting Libraries (\%) & Increased Percentage \\
\hline RSS & $30(27 \%)$ & $110(99 \%)$ & $72 \%$ \\
\hline Blog & $8(7.2 \%)$ & $85(77 \%)$ & $69.8 \%$ \\
\hline Tagging & $3(2.7 \%)$ & $77(69 \%)$ & $65.3 \%$ \\
\hline Podcast & $2(1.8 \%)$ & $37(33 \%)$ & $31.2 \%$ \\
\hline Wiki & $2(1.8 \%)$ & $24(22 \%)$ & $20.2 \%$ \\
\hline
\end{tabular}

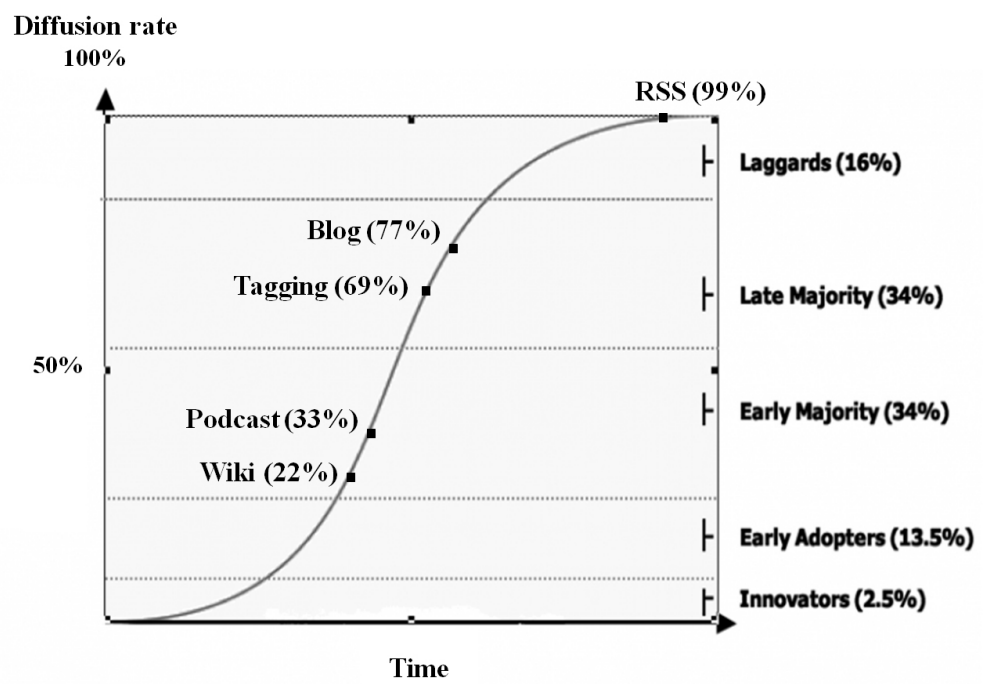

〈Figure 1〉 Categories of Web 2.0 Adopting Libraries

for subsequent adopters with sufficient money and time to invest in an innovation. They are the next $13.5 \%$ of adopters. Podcasts are also currently being adopted by early majority adopters. Early majority adopters are deliberate before adopting a new innovation and they are less affluent and have less education than innovators and early adopters. They account for up to $34 \%$ of adopters. Tagging and blogs are currently being adopted by late majority adopters and this group constitutes another 34\%. Late majority adopters are cautious, conservative, and very cost-sensitive.

\subsection{Factors Associated with the Adoption of Web 2.0}

The logistic regression analysis results indicate that a significant difference was found only with the adopters and non-adopters of wikis $\left(\mathrm{X}^{2}(8)=.029\right.$, $\mathrm{p}<.05 ;-2 L L=97.277$, Nagelkerke $R^{2}=0.238$ ). The adopters of RSS, blogs, tagging, and podcasts are not significantly different from their non-adopters 
〈Table 5〉 Logistic Regression Analysis of Variables Associated with the Adoption of Wiki

\begin{tabular}{c|c|c|c}
\hline \hline Variables & $\beta$ & Wald (del) & Sig. $^{*}$ \\
\hline SERPURE & .000 & 8.511 & .004 \\
\hline COMPFIL & .000 & .010 & .920 \\
\hline TOTEXP & .000 & .175 & .675 \\
\hline EXPESERL & .000 & .026 & .871 \\
\hline TOTSTFX & -.014 & 3.430 & .064 \\
\hline PRFSTF & .027 & 4.022 & .045 \\
\hline REFTRANS & .000 & .862 & .353 \\
\hline TOTCIRC & .000 & .305 & .581 \\
\hline TOTSTU & .000 & 8.941 & .003 \\
\hline Constant & -.486 & .313 & .576 \\
\hline
\end{tabular}

Note: Nagelkerke $\mathrm{R}^{2}=0.238 * \mathrm{p}<.05$

on any variables. This might be because the adoption of those applications has considerably penetrated in the sampled libraries whereas the wiki adopters are mostly innovators and early adopters. Consistent with the findings of Helgren and Lietzau (2011), and White (2001), the adopter libraries of wikis, mostly early adopters, seem to possess unique characteristics, distinguished from the non-adopters.

The statistical analysis further identified three institutional variables that are most strongly associated with the adoption of wikis: (1) total full-time student enrollment (TOTSTU), (2) total professional staff, including librarians (PRFSTF) and (3) number of electronic serials titles (SERPURE) (Table 5). This result is interpreted to mean that libraries more likely to adopt wikis are in larger institutions, have more professional staff to spare, and are more acceptable to electronic resources.

However, neither 'total expenditures' (TOTEXP) nor 'expenditures for electronic serials' (EXPESERL) was associated with the adoption of wikis. This is probably because by using free software, no cost is usually incurred to provide new wiki services. The training costs incurred in developing and maintaining a wiki are also low because wikis are relatively easy to use and do not require professional computer skills. Moreover, no variable associated with 'demands for services' turned out to be related to the adoption of wikis. This means that wiki adoption does not increase demands for library services as evidenced as total circulation and the number of reference transactions. Finally, the number of computer files (COMPFIL), which refers to the number of files stored in CD-ROMs, magnetic tapes, and other old media, was not related to wiki adoption.

\section{Discussion}

All ARL member libraries surveyed in this study provided at least one and on average three Web 2.0 applications. Considering the extent of adoption of 
the five popular Web 2.0 applications and their increasing adoption since 2006 to today, Web 2.0 is still a fashionable technology that is on the rise in academic libraries in the U.S.

The order of popularity of the Web 2.0 applications implemented in the ARL libraries is generally consistent with previous research (Kim and Abbas 2010): RSS, blogs, tagging, podcasts, and wikis. One of the reasons behind the popularity of RSS and tagging is that many library systems and Web 2.0 platforms offering RSS and/or tagging built-in have lowered the barriers to implement the technologies. Instead of creating their own RSS or tagging services from scratch, librarians can select a system that includes the technologies. The adoption of RSS is practically complete and tagging is expected to maintain an upward course if more library systems provide the technology as a default feature. In the current study, however, it is not known if the presence of those technologies as a built-in feature was a factor in adopting a particular system or if those technologies just came along as part of the package without librarians necessarily having the intention to make full use of them. This issue is important because the success of an innovation depends on adopters' commitment. Those adopters who commit themselves to acquire and sustain an innovation are more likely to promote the innovation to facilitate its use. Therefore, future research should delve into the decision-making on the purchase of a library system that may entail consideration of Web 2.0 adoption.

Blogs, the second most popular Web 2.0 application, have spread considerably in ARL libraries over the past years. However, evidence has emerged that the popularity of blogs is waning in favor of the immediacy of Facebook and Twitter. Torres-Salinas et al. (2011) showed a loss of significance for blogs as a communication medium for the library and information science community, as indicated by the closure of over $50 \%$ of blogs and the reduction in gross number of posts being published between 2006 and 2009. Pew Report noted that blogging among the young declined by half during the same period, and more people were turning to Facebook and Twitter (Sebastian 2011).

Podcasts and wikis are still being examined for their applicability within the library environment. As these technologies require a certain amount of time and effort for librarians to develop rather than being provided as a built-in feature of a bigger system, their adoption is unlikely to take off sharply in the near future.

When it comes to the factors that possibly encourage the adoption of Web 2.0, the adopters of wikis, mostly innovators or early adopters, differed from the non-adopters in terms of total students, total professional staff including librarians, and total number of electronic serials titles. This finding corroborates or contradicts the results of previous studies as follows:

- The present study confirms that larger libraries tend to be more innovative (Helgren and Lietzau 2011; White 2001). White viewed size as a stand-in measure for other variables such as staff expertise and the availability of slack resources, which may encourage entrepreneurship 
in establishing new services. It is also possible that a large client base helps create a critical mass of potential users for new service development. Especially for a wiki designed for collaborative work, the scale of potential users can be a factor in the decision to adopt this Web 2.0 application.

- Previous research shows that libraries with larger financial and human resources can allocate more funding and staff towards adopting a new technology (Helgren and Lietzau 2011; White 2001). It is clear that additional staff makes it easier to implement a new technology within a library. Due to the availability of free wiki authoring sites, however, high funding is not a prerequisite to adopting a wiki in the current study. This may hold true for other Web 2.0 applications that require low costs for installation and maintenance.

- The current study corroborates White's finding that libraries that have already provided electronic resources or services such as distributed access to electronic serials are more likely to embrace a new technology. The total number of electronic serials titles can translate into the degree of acceptance of electronic resources for information access and this variable was found to be associated with wiki adoption. On the other hand, the number of computer files in CD-ROM and magnetic tapes had no relationship with wiki adoption. Because CD-ROMs and magnetic tapes are now old media used for storage and backups, this variable does not seem to be an adequate indicator of the degree of acceptance of new electronic resources.

- Helgren and Lietzau (2011) statistically proved that Web 2.0 adoption facilitated the use of libraries as evidenced by library visits and circulation. It should be noted that in their study, early adopter libraries were determined by the collective points awarded based on the adoption of each application and thus, they were early adopters of Web 2.0 as a whole. The present study found that the sole adoption of wikis did not boost the circulation of library materials and the number of reference transactions. Future research is needed to investigate what benefits, if any, wikis and other Web 2.0 applications bring to academic libraries individually and collectively.

Furthermore, none of the variables were found to be associated with the adoption of RSS, blogs, tagging, or podcasts. A possible reason is that the relatively high degree of adoption of these technologies made less prominent the differences between the characteristics of the adopters and those of the non-adopters, resulting in a homogeneous group of libraries. Another interpretation could be that institutional factors are not very influential in adopting those technologies. Instead, the inherent attributes of each Web 2.0 application (e.g., a podcast requires considerable time and effort to develop) and internal factors, such as highly motivated librarians, may be more important. 


\section{Limitations and Future Research}

The present study has several limitations. First, with a focus on institutional variables, other factors were ignored in adopting Web 2.0 applications such as individual librarians' motivation and attitudes towards the adoption of new technologies. Second, only publicly available Web 2.0 applications were included. This may have understated some Web 2.0 applications that were used for internal use. Third, as mentioned earlier, it is not known from this research that the librarians adopted, for example, an online public access catalog system considering the availability of a tagging function within it or if the function just came along as part of the system with the librarians having no intention to utilize it. Fourth, this study did not measure the quality or usage of each Web 2.0 service.

The following areas of future research are recommended as a result of the issues raised here: (1) Internal factors associated with Web 2.0 adoption such as expertise and motivation of librarians should be investigated; (2) another area could be the examination of the adoption by individual librarians and actual use of library clients; and (3) the impact of Web 2.0 adoption on library performance should be explored and determined.

\section{Conclusion}

While prior work in this area has primarily focused on providing a snapshot of the current state of Web 2.0 applications, the present study adds to the existing knowledge by also showing the adoption trend over time and exploring factors associated with the adoption of Web 2.0. Major findings are: (1) The popularity of Web 2.0 continues to grow, both in terms of the total number of adopting libraries and the adoption rate, (2) wiki adopter libraries are in larger universities, have larger professional staff, and are more acceptable to electronic resources than the non-adopters, and (3) the sole adoption of wikis does not increase circulation and reference transactions.

\section{References}

이현실. 2007. 대학도서관 2.0에서 사서의 업무 방향.

『한국비블리아학회지』, 18(1): 147-168.

이응봉. 2007. 학술도서관 디지털정보서비스의 향후 전망.

『한국문헌정보학회지』, 41(2): 181-202.

이지연, 민지연. 2008. 라이브러리 2.0에 대한 이용자
인식 및 요구사항에 관한 실증적 연구.『한국문헌 정보학회지 , 42(1): 213-231.

노영희. 2010. 도서관 3.0 의 개념과 서비스 모형에 관한 연구. 『정보관리학회지』, 27(4): 283-307. 신수연, 김성민. 2010. 도서관 2.0 시대의 사서 2.0 에게 
기대되는 역할에 관한 연구. 『정보관리학회지』, 27(2): 201-216.

Association of Research Libraries (ARL). 2011.

Machine-Readable ARL Statistics 2008-2009. [cited 2012.6.21].

$<$ http://www.arl.org/stats/annualsurveys/arlst ats/mrstat.shtml $>$.

Bennington, A. 2007. "Stick It in Your Ear: Keeping Current with Podcasts." Online, 31: 30-32.

Boxen, J. L. 2008. "Library 2.0: A Review of the Literature." The Reference Librarian, 49: 21-34. Chatfield, A. J., M. A. Ratajeski, J. Wang, and T. P. Bardyn. 2010. "Communicating with Faculty, Staff, and Students Using Library Blogs: Results from a Survey of Academic Health Sciences Libraries." Internet Reference Services Quarterly, 15: 149-168.

Corrocher, N. 2011. "The Adoption of Web 2.0 Services: An Empirical Investigation.” Technological Forecasting and Social Change, 78 : 547-558.

Clyde, L. A. 2004. "Library Weblogs.” Library Management, 25: 183-189.

Crawford, W. 2006. "Library 2.0 and 'Library 2.0'." Cites \& Insights: Crawford at Large, 6: 32. Harinarayana, N. S. and N. V. Raju. 2010. "Web 2.0 Features in University Library Web Sites." The Electronic Library, 28: 69-88.

Helgren, J. E. and Z. Lietzau. 2011. "U.S. Public Libraries and Web Technologies: What's Happening Now?" Computers in Libraries, 31: $12-16$

Kim, Y. and J. Abbas. 2010. “Adoption of Library
2.0 Functionalities by Academic Libraries and Users: A Knowledge Management Perspective." Journal of Academic Librarianship, 36: $211-218$.

Liu, S. 2008. "Engaging Users: The Future of Academic Library Web Sites." College \& Research Libraries, 69: 6-27.

Mahmood, K. and J. V. Richardson Jr. 2011. "Adoption of Web 2.0 in US Academic Libraries: A Survey of ARL Library Websites." Program: Electronic Library and Information Systems, 45: 365-375.

Maness, J. M. 2006. “Library 2.0 Theory: Web 2.0 and Its Implications for Libraries." Webology, 3. Articles 25. [cited 2012.6.21]. $<$ http://www.webology.org/2006/v3n2/a25.h tml>.

Moser, F. 2011. "Evaluating IT Fashion Investments Regarding Risk and Return.” AMCIS 2011 Proceedings - All Submissions, Paper 207. [cited 2012.6.21]. $<\mathrm{http}$ //aisel.aisnet.org/amcis2011_submissio ns/207>.

Neilson, C. 2008. "Current Awareness on a Shoe String: RSS at the HQC." Internet Reference Services Quarterly, 13: 57-67.

O'Reilly, T. 2005. “What Is Web 2.0?” [cited 2012.6.21]. $<$ http://oreilly.com/web2/archive/what-is-we b-20.html>.

Rogers, E. M. 1995. Diffusion of Innovations. New York: The Free Press.

Sebastian, M. 2011. Pew Report: Popularity of Blogs Plummets among Young. [cited 2012.6.21]. 
$<$ http://www.prdaily.com/Main/Articles/Pew

_Report_Popularity_of_blogs_plummets_am ong_youn_7285.aspx $>$.

Thornton, E. 2009. "iTunes University and ARL Academic Libraries." Journal of Web Librarianship, 3: 263-272.

Torres-Salinas, D., Á. Cabezas-Clavijo, R. Ruiz-Pérez, and E. D. López-Cózar. "State of the Library and Information Science Blogosphere after Social Networks Boom: A Metric Approach." Library and Information Science Research, 33: 168-174.

Tripathi, M. and S. Kumar. 2010. "Use of Web 2.0 Tools in Academic Libraries: A Reconnaissance of the International Landscape." The International Library Review, 42: 195-207.
Wang, P. 2010. "Chasing the Hottest IT: Effects of Information Technology Fashion on Organizations." MIS Quarterly, 34: 63-85.

White, M. D. 2001. "Diffusion of an Innovation: Digital Reference Service in Carnegie Foundation Master's (Comprehensive) Academic Institution Libraries." Journal of Academic Librarianship, 27: 173-187.

Yakel, E. and J. Kim. 2005. "Adoption and Diffusion of Encoded Archival Description.” Journal of the American Society of Information Science and Technology, 56: 1427-1437.

Yoose, B. 2011. "Wiki Adoption and Use in Academic Library Technical Services: An Exploratory Study." Technical Services Quarterly, 28: 132-159. 